УДК 595.142.3

\author{
О. М. Кунах \\ Дніпропетровський національний університет ім. Олеся Гончара
}

\title{
ОРДИНАЦІЯ ТА СІТЬОВИЙ АНАЛІЗ УГРУПОВАНЬ ПАВУКІВ
}

Запропоновано сітьовий підхід до вивчення угруповань тварин на прикладі герпетобіонтних павуків Дніпропетровської області. Сітьове відображення - альтернатива ординаційній парадигмі при описі структури угруповань. Показано переваги сітьового підходу в екологічному аналізі тваринного населення. Встановлено можливі напрями формування угруповань герпетобіонтних павуків степової зони Украйни. Показано вплив на формування тваринного населення степу лісових масивів.

$$
\text { О. Н. Кунах }
$$

Днепропетровский нащиональный университет им. Олеся Гончара

\section{ОРДИНАЦИЯ И СЕТЕВОЙ АНАЛИЗ КОМПЛЕКСОВ ПАУКОВ}

Предложен сетевой поход для изучения сообществ животных на примере герпетобионтных пауков Днепропетровской области. Сетевое отображение - альтернатива ординационной парадигмы в описании структуры сообществ. Показаны преимущества сетевого подхода в экологическом анализе животного населения. Выявлены возможные пути формирования сообществ герпетобионтных пауков степной зоны Украины. Показано влияние на формирование животного населения степи лесных массивов.

\author{
O. M. Kunakh \\ Oles' Gonchar Dnipropetrovsk National University \\ ORDINATION AND NETWORK ANALYSIS \\ OF THE SPIDER COMMUNITY
}

The network approach is proposed to study the animal community with herpetobiont spiders of Dnipropetrovsk region as an example. The network representation is an alternative of an ordination paradigm in community structure description. The advantages of the network approaches in animal community analysis are shown. The possible directions of the herpetobiont spiders community formation of the steepe zone of Ukraine have been found. The effect of the forests on the steepe animals community is shown.

\section{Вступ}

У генетичних дослідженнях широко використовуються технології побудови філогенетичних сіток і дерев на основі відомостей про послідовності структурних компонентів біомолекул (ДНК, РНК, білки). Подібні підходи застосовуються в лінгвістичних дослідженнях. Характерна риса сітьового аналізу - побудова сітки, що найвірогідніше відбивала б послідовність розвитку дослідженого явища. Сітьовий підхід не новий в екології. Видатні екологи Р. Лінденман і Г. Одум були першими, хто застосував сітки для відображення та опису трофічних взаємозв'язків в угрупованнях [8; 12]. Широко використовується сітьовий підхід для візуалізації трофічних мереж $[4 ; 14]$, а також нетрофічних екологічних взаємодій $[5 ; 11 ; 13]$. Мережі $з$ прямими ребрами (так звані 
плексусні діаграми) давно використовуються як основа вивчення взаємин між видами, взаємодії видів із навколишнім середовищем [6; 7; 9; 10; 17], однак такий підхід не поширений, йому віддають перевагу класифікаційні та ординаційні техніки [15].

Важливий аспект застосування сіток в екології - просторові мережі [3]. Теорія графів, що лежить в основі сітьового підходу, може бути привнесена у ландшафтну екологію як спосіб узагальнення процесу фрагментації територіальних комплексів і його ролі у функціонуванні угруповань. Класична робота у цьому напрямку - дослідження Д. Урбана та Т. Кейта [16].

Сітка - це структурований граф, що складається із сукупності вузлів, пов'язаних між собою ребрами.

Побудова сітки в цьому дослідженні відбувалася за алгоритмом медіанних сіток [2]. Із метою досягти максимальної парсимонії уводяться додаткові вузли - медіанні вектори, або Штейнерові точки. Медіанні вектори з біологічного погляду можуть бути інтерпретовані як існуючі, але не враховані при збиранні даних об’єкти.

Усяке дослідження виконується у рамках тих або інших припущень про властивості дослідженого об'єкта та «дозволених» методів дослідження його властивостей. На ці припущення накладаються обмеження певного роду, що відповідають умові конструктивності. Вони формулюються принципом економії (парсимонії - від англ. parsimony; також простоти), який має загальнонаукове значення [1].

Епістемологічний зміст принципу економії базується на ідеях середньовічного теолога У. Оккама, який проголосив гасло «відтинати все понад необхідне» при поясненні пізнаваних сутностей. Звідси алегорична назва принципу - «лезо Оккама». Уже в наш час це було названо «економією мислення», що означає мінімізацію допущень про причини, що породжують досліджене явище - наприклад, біологічне різноманіття. Іншими словами, чим простіше пояснення, тим більше йому довіри. Із цього погляду, з двох моделей, що однаково ефективно описують об'єкт, спроможніша та, яка включає менше параметрів: вона «ощадливіша».

Онтологічний зміст грунтується на тезі одного з ранніх філософів-позитивістів Д. Юма про «простоту Природи». Пізніше це вилилося у формулу розвиненого позитивізму: «світ простий і тому припускає прості описи». Є серйозні підстави сумніватися у розумності цього твердження: насправді світ не настільки простий, щоб його можна було описати простими формулами [1].

У філогенетиці два загальні розуміння принципу економії (парсимонії) реалізовані у двох концепціях. Він або вводиться у явному вигляді як частина онтологічного базису: певний «ощадливий» характер приписується еволюційному процесу. Це - еволюційна парсимонія. Або він неявно присутній в алгоритмах, орієнтованих на мінімізацію вихідних допущень про еволюцію: це - методологічна парсимонія. Наслідок еволюційної парсимонії - модель мінімальної еволюції: вона припускає найменше число подій філогенезу, які призвели до спостережуваного різноманіття організмів. Такі події, у першу чергу, - окремі зміни властивостей організмів. Відповідно, чим рідкісніші повтори цих подій в еволюції (тобто чим менше в ній паралелизмів, що призводять до гомопластичної подібності), тим вона «ощадливіша» [1].

Із погляду принципу максимальної парсимонії в кладистиці віддають перевагу таким філогенетичним деревам, які відповідають найменшим еволюційним змінам. У біогеографії принцип парсимонії використовується для визначення міграції видів $\mathrm{i}$ популяцій виходячи з їх географічного поширення. Найімовірнішими приймаються такі міграційні процеси, які вимагають найменших витрат для переміщення. 
При методологічному трактуванні принципу економії сам характер еволюційного процесу, строго кажучи, не чіпається: історичному розвитку не приписується неодмінно «ощадливий» характер. У цьому випадку «ощадлива» сукупність суджень про еволюцію: ключовою стає вимога мінімізації обсягу апріорних тверджень про властивості цього процесу. Виходячи з цього приймається, що з філогенетичних гіпотез, при інших рівних, переважніша та, яка отримана при найменшій кількості апріорних допущень про характер еволюції. Відповідно до даного критерію, за допомогою «леза Оккама» у першу чергу відтинаються (як мало обгрунтовані) властиві класичній філогенетиці міркування про адаптивний і спрямований характер еволюції, про ймовірності паралелизмів і реверсій [1].

\section{Матеріал і методи досліджень}

Аналізу були піддані дані про структуру населення павуків із таких місцеперебувань (цифри вказують на умовні коди-ідентифікатори, під якими біогеоценози зустрічаються у подальшому у тексті та рисунках).

Байрак Військовий. Північна експозиція, верхня третина: 1000 - степова цілинка, 1001 - бересто-пакленова діброва з грястицею. 1002 - північна експозиція, середня третина, липо-ясенева діброва із зірочником. 1003 - північна експозиція, нижня третина, липоясенева діброва 3 широкотрав'ям. 1004 - тальвег, пакленова діброва з яглицею. 1005 - південна експозиція, нижня третина, бересто-ясенева діброва з келерією лісовою. 1006 - південна експозиція, середня третина, бересто-ясенева діброва з фіалкою шершавою. 1007 південна експозиція, верхня третина, бересто-чорнокленовий дубняк із грястицею.

Байрак Яиів яр. Північна експозиція, верхня третина: 1008 - бересто-пакленова діброва $з$ грястицею, 1009 - степова цілинка. 1010 - північна експозиція, середня третина, липо-ясенева діброва із зірочником. 1011 - північна експозиція, нижня третина, липо-ясенева діброва 3 широкотрав'ям. 1012 - тальвег, пакленова діброва 3 яглицею. 1013 - південна експозиція, нижня третина, бересто-ясенева діброва 3 келерією лісовою. 1014 - південна експозиція, середня третина, степова цілинка.

Балка Бандурка. 1015 - тальвег, пакленова діброва 3 яглицею. 1016 - південна експозиція, нижня третина, пакленова діброва з яглицею. 1017 - степова цілинка. 1018 південна експозиція, верхня третина, степова цілинка.

Балка поблизу с. Нововоронщовка (урочище Осокорівка, Херсонська область). 1019 - північна експозиція, нижня третина, лісове насадження. 1020 - тальвег, зарості грецького горіха. 1021 - південна експозиція, нижня третина, лісове насадження, чагарник. 1022 - південна експозиція, середня третина, чагарник у степу. 1023 - петрофільний степ. 1024 - південна експозиція, верхня третина, петрофільний степ.

Заплава р. Оріль. 1025 - бересто-чорнокленовий дубняк із розхідником звичайним. 1026 - бересто-чорнокленовий дубняк із конвалією. 1027 - болотистий луг.

Заплава р. Самара. Прируслова заплава: 1028 - липова діброва 3 широкотрав'ям, 1029 - липова діброва $з$ грястицею збірною, 1030 - липова діброва із зірочником. Притерасна заплава: 1031 - в'язо-ясенева діброва 3 яглицею, 1032 - ольс із болотяним великотрав'ям, 1033 - ольс із сирим великотрав'ям. Центральна заплава: 1034 - липоясенева діброва 3 пухнатою осокою, 1035 - липо-ясенева діброва 3 широкотрав'ям, 1036 - липо-ясенева діброва із зірочником.

Урочище Круглик. 1037 - 100 м на схід від урочища, заплавний луг. 1038 - 200 м від східного узлісся, липо-ільмова діброва $з$ яглицею. 1039 - східне узлісся урочища, пакленоясенева діброва 3 широкотрав'ям. 1040 - центр урочища, липо-ільмова діброва 3 яглицею. 
Правий берег р. Самара, пристін. 1041 - верхня третина схилу, бересточорнокленовий дубняк із грястицею. 1042 - середня третина, бересто-чорнокленовий дубняк із грястицею.

Чорний ліс (Кіровоградська область). 1043 - північна експозиція, верхня третина, липо-грабова діброва 3 широкотрав'ям. 1044 - північна експозиція, середня третина, липо-ясенева діброва з широкотрав'ям. 1045 - північна експозиція, нижня третина, липо-ясенева діброва 3 яглицею. 1046 - тальвег, в'язо-ясенева діброва із сирим великотрав'ям. 1047 - плакор, бересто-пакленова діброва з грястицею.

Для проведення сітьового аналізу використали програму Network 4.5.1.0 (http://www.fluxus-technology.com). Ця програма призначена для реконструкції усіх можливих найпростіших філогенетичних дерев на основі наявних відомостей. Нами використаний алгоритм побудови медіанних сіток. За основу взяті бінарні дані. Дані про чисельність тварин попередньо логарифмували та стандартизували. Кожна континуальна змінна замінена трьома бінарними змінними. Перша бінарна змінна набирає значення «0», якщо значення континуальної змінної дорівнює нулю, або «1» - якщо більше нуля. Друга бінарна змінна набирає значення «0», якщо значення континуальної змінної не більше 0,33 стандартного відхилення $(\sigma<1 / 3)$ i «1» - у протилежному випадку $(\sigma>1 / 3)$. Третя бінарна змінна набирає значення «0», якщо значення континуальної змінної не більше 0,66 стандартного відхилення $(\sigma<2 / 3)$ i «1»- у протилежному випадку. Для аналізу таксономічної структури угруповань павуків відібрані такі види, які в наших зборах були зустрінуті не менше ніж у 6 біогеоценозах (таких видів виявилося 32 ).

\section{Результати та їх обговорення}

На рисунку 1 можна чітко виділити кілька гілок-кластерів (позначені A-F). Медіанна сітка складається з вузлів і зв'язків між ними. Вузли - досліджувані об’єкти або медіанні вектори. Медіанний вектор - це гіпотетичний об'єкт (вузол), необхідний для об’єднання реальних об'єктів у сітку з найбільшою точністю (збільшена область рис. 1 рис. 2). Зв'язки між об'єктами встановлюються за ключовими розбіжностями, які виникають у результаті мутацій (за аналогією з вивченням генетичних даних). У випадку з екологічними даними зв'язки відповідають індикаторним видам, які визначають специфіку вузлів.

На рисунку 2 як приклад детально показано природу зв’язку між вузлом 1022 і медіанним вектором mv3. Як видно з рисунка, цей зв'язок утворюють мутації чисельності павука Asianellus festivus (C. L. Koch, 1834), які можна інтерпретувати як зменшення чисельності цього виду від вузла 1022 до медіанного вектора mv3. Крім того, у формуванні ребра бере участь Harpactea rubicunda (C. L. Koch, 1838): мутація чисельності цього виду $2 / 3=\sigma \epsilon$ важливою в розмежуванні $1022 \mathrm{i} \mathrm{mv3.} \mathrm{Із} \mathrm{міркувань} \mathrm{наочності}$ така інформація не показана на рисунку 2 , однак вона важлива для інтерпретації отриманої конфігурації сітки.

На рисунку 1 центральну область займає кластер, складений із біогеоценозів Чорного лісу (кластер А). Характерна риса цього комплексу видів - Agroeca brunnea (Blackwall, 1833). 3 іншими біогеоценозами степового Придніпров'я угруповання павуків Чорного лісу пов'язані через місцеперебування в долині р. Самара (заплава ріки та правий берег). Перехід до інших угруповань пов'язаний з появою високої чисельності Arctosa lutetiana (Simon, 1876), що не характерно для угруповань у Чорному лісі та у заплаві p. Самара. До групи угруповань Чорного лісу за складом домінантних видів павуків близькі угруповання прируслової заплави р. Самара (1028). 
Можна виділити два напрямки трансформації таксономічної структури угруповань павуків від кореневого комплексу видів у Чорному лісі. Це комплекси лісових угруповань байраків Військовий і Яців яр (кластер C), а також урочища Круглик і заплави p. Оріль (кластер В) - з одного боку, та інші угруповання - 3 іншого (кластери D, F).

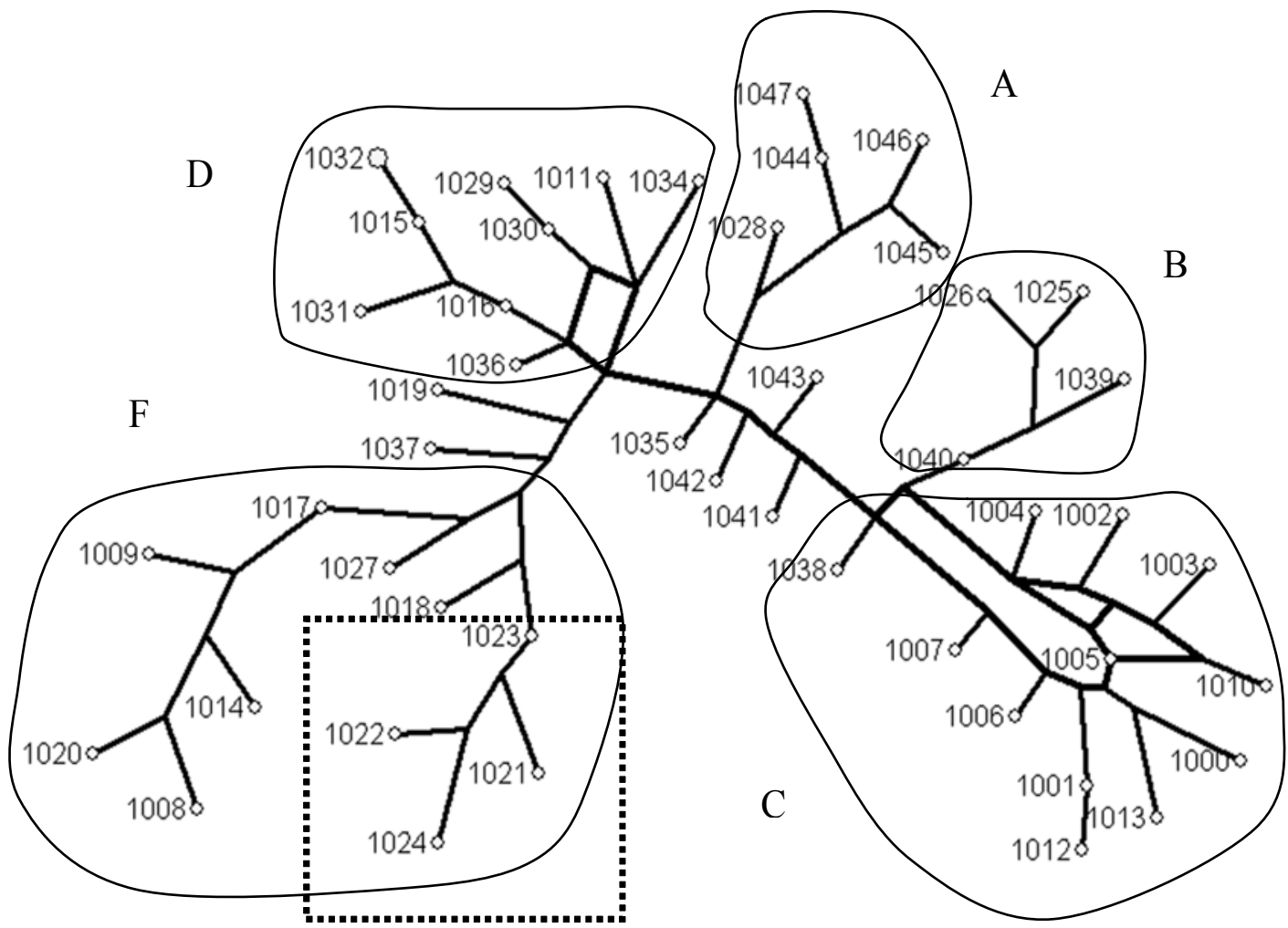

Рис. 1. Сітьовий аналіз структури угруповань павуків на основі даних

про чисельність домінантних видів: A-F - кластери; нумерація БГЦ - див. у тексті; прямокутник, позначений штрих-пунктиром - див. рис. 2.

Індикатором комплексу видів байраків Військовий, Яців яр (в останньому випадку - це біогеоценози, наближені до тальвегу), урочища Круглик і заплави р. Оріль (кластери В і C) є Pisaura mirabilis (Clerck, 1757). Для заплави р. Оріль (кластер В) характерний Alopecosa pulverulenta (Clerck, 1757), де він демонструє високу чисельність. Зустрічається Zora spinimana (Sundevall, 1833), однак його чисельність нижча, ніж у байраку Військовий. Також для заплави р. Оріль характерний Diplocephalus picinus (Blackwall, 1841), який із вищою чисельністю трапляється також у Чорному лісі. За складом видів-домінантів угруповання урочища Круглик близькі до угруповань павуків у заплаві р. Оріль. Як для заплави р. Оріль, так і для урочища Круглик, характерна висока чисельність Trochosa terricola Thorell, 1856 і T. ruricola (De Geer, 1778).

Для біотопів південної експозиції байраку Військовий особливо характерні Agroeca cuprea Menge, 1873 i Zelotes electus (C. L. Koch, 1839). У байраку Військовий i частково у байраку Яців яр, а також у біогеоценозах заплави р. Оріль, часто трапляється Zora spinimana (Sundevall, 1833). Типовий для байрачних лісів вид - Harpactea rubicunda (C. L. Koch, 1838). Важливий кластер у протилежному напрямку - група угруповань заплави р. Самара та іï правий берег (кластер D). До цього кластера примикають балкові 
угруповання урочища Яців яр (переважно верхні третини схилів - 1008, 1009, 1014), а також балки Бандурка (1017) і урочища Осокорівка (1020) (кластер F).

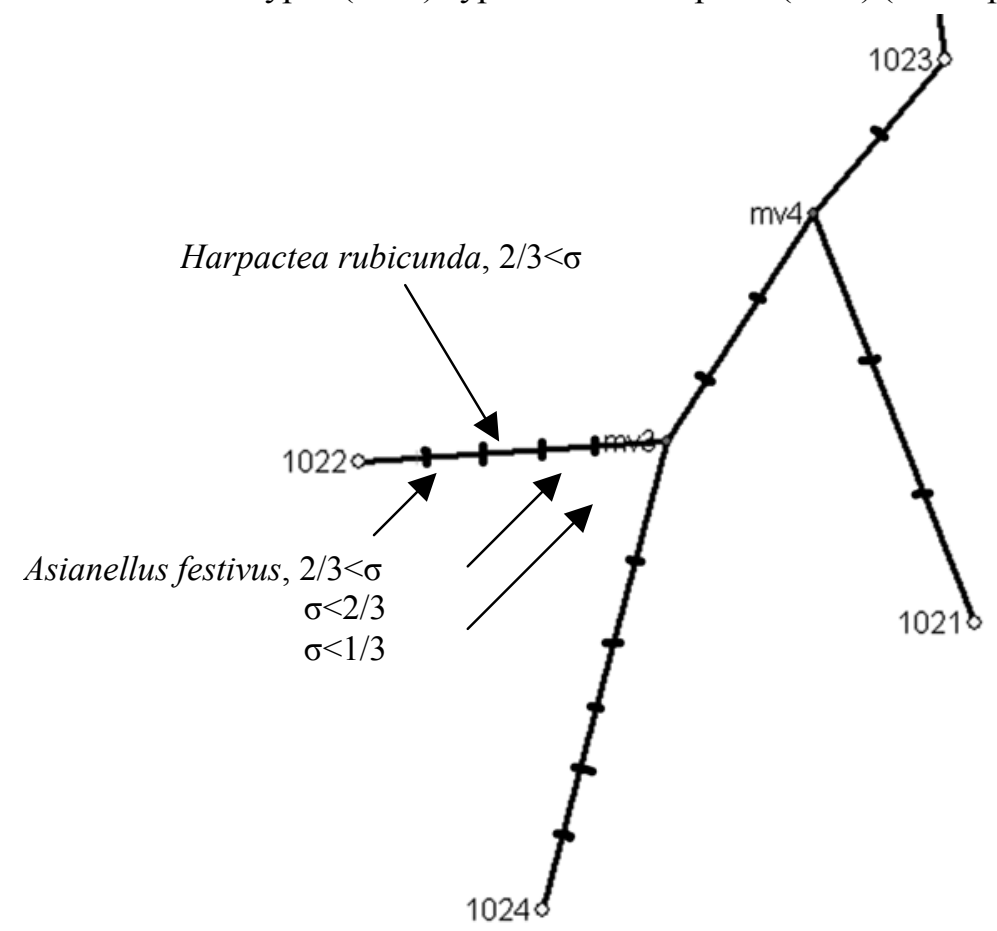

Рис. 2. Збільшена область, позначена на рис. 1 штрих-пунктиром:

1021-1024 - див. текст; mv3, mv4 - медіанні вектори; штрихи на ребрах - позиції мутацій

Кластер F відрізняється від інших угруповань відносно нижчим рівнем чисельності Ozyptila praticola (C. L. Koch, 1837) або його відсутністю. У свою чергу, угруповання заплави р. Самара від байрачних комплексів відрізняються відносно низькою чисельністю Pardosa lugubris (Walckenaer, 1802) i Trochosa terricola і вищою-Ozyptila praticola.

Сітьовий аналіз - не альтернатива ординаційним технікам. Ординаційний підхід або ієрархічний кластерний аналіз - деяке спрощення сітьової структури, яка $є$ природнішим відображенням реальної організації тваринного населення. Ординація у вигляді добре розвинених статистичних процедур (аналіз головних компонент, аналіз відповідностей, багатовимірне шкалювання, градієнтний аналіз тощо) або ієрархічний кластерний аналіз - досить сильні інструменти вивчення угруповань тварин. Але ця сила має свою ціну: передумови, на яких базуються відповідні підходи, можуть значно змінити реальну картину взаємозв'язків природного об'єкта. Існує досить сильна спокуса надати реальному об'єкту властивості, яких у нього немає, але вони виникають внаслідок саме застосування певної статистичної процедури. Від цього недоліку не вільна ніяка процедура, але сітьовий підхід залишає значний простір для можливих у межах модельного підходу комбінацій, які, вірогідно, існують у реальному світі.

Недолік застосованої процедури - груба аналогія 3 мутаційним процесом, від вивчення якого запозичена сама комп'ютерна програма для обробки даних. Вірогідніший континуальний характер формування зв'язків між угрупованнями. Квантування континуальних взаємозв'язків приховує елемент суб'єктивного визначення меж, яке може суттєво впливати на результати відображення природного процесу.

Визначення стійкості результуючої конфігурації від умов квантування - цікавий напрям дослідження сітьової моделі. 


\section{Висновки}

Застосування сітьового підходу дозволило встановити, що джерело формування інтразональних фауністичних елементів степової зони - лісові угруповання лісостепу, які в нашому дослідженні представлені комплексами Чорного лісу. Значну близькість за таксономічною структурою до лісостепових комплексів демонструють угруповання байраку Військовий та деякі угруповання заплави р. Самара. Байрак Військовий має щільний контакт із пристінними комплексами р. Дніпро. Очевидно, що проникнення інтразональних елементів у межі степової зони здійснювалося заплавними екосистемами степових рік. Цілком імовірно, що процес розселення складався 3 декількох етапів, що зумовило фауністичні особливості екологічно подібних комплексів.

\section{Бібліографічні посилання}

1. Павлинов И. Я. Введение в современную филогенетику (кладогенетический аспект). - М. : КМК, 2005. - $192 \mathrm{c}$.

2. Bandelt H.-J. Median-joining networks for inferring intraspecific phylogenies / H.-J. Bandelt, P. Forster, A. Rohl // Mol. Biol. Evol. - 1999. - Vol. 16 (1). - P. 37-48.

3. Bascompte J. Networks in ecology // Basic and Applied Ecology. - 2007. - Vol. 8. - P. 485-490.

4. Interaction strengths in food webs: issues and opportunities / E. L. Berlow, A.-M. Neutel, J. E. Cohen et al. // Journal of Animal Ecology. - 2004. - Vol. 73. - P. 585-598.

5. Brose U. From food webs to ecological networks: Linking non-linear trophic interactions with nutrient competition / U. Brose, E. L. Berlow, N. D. Martinez // P. C. de Ruiter, V. Wolters, J. C. Moore (Ed.) Dynamic Food Webs: Multispecies Assemblages, Ecosystem Development and Environmental Change. - NY : Academic Press, 2005. - P. 27-36.

6. Dale M. B. On plexus representation of dissimilarities // Community Ecology. - 2000. - Vol. 1. P. 43-56.

7. Gillison A. N. Minimum spanning ordination - a graphic-analytical technique for three-dimensional ordination display // Austral Ecology. - 1978. - Vol. 3. - P. 233-238.

8. Lindenman R. L. The trophic-dynamic aspect of ecology // Ecology. - 1942. - Vol. 23. - P. 399-418.

9. Matthews J. A. An application of non-metric multidimensional scaling to the construction of an improved species plexus // Journal of Ecology. - 1978. - Vol. 66. - P. 157-173.

10. McIntosh R. P. Matrix and plexus techniques // R. H. Whittaker (Ed.) Ordination and Classification of Communities. - Junk : The Hague, 1973. - P. 159-191.

11. Memmott J. The structure of a plant-pollinator food web // Ecological Letters. - 1999. - Vol. 2. P. 276-280.

12. Odum H. T. Primary production in flowing waters // Limnology and Oceanography. - 1956. Vol. 1. - P. 102-117.

13. Paine R. T. Ecological determinism in the competition for space // Ecology. - 1984. - Vol. 65. P. $1339-1348$.

14. Pimm S. L. The complexity and stability of ecosystems // Nature. - 1984. - N 307. - P. 321-326.

15. Raymond B. Network-based exploration and visualisation of ecological data / B. Raymond, G. Hosiea // Ecological Modelling. - 2009. - Vol. 220, is. 5. - P. 673-683.

16. Urban D. Landscape connectivity: A graph-theoretic perspective / D. Urban, T. Keitt // Ecology. 2001. - Vol. 82, N 5. - P. 1205-1218.

17. Whittaker R. H. A study of plankton copepod communities in the Columbia Basin, Southeastern Washington / R. H. Whittaker, W. C. Fairbanks // Ecology. - 1958. - Vol. 39. - P. 46-65.

Надійшла до редколегї 12.01. 2010 